OPEN ACCESS

Edited by:

Guobin Fu,

CSIRO Land and Water, Australia

Reviewed by:

Feng Li,

Institute of Subtropical Agriculture (CAS), China

Xinhou Zhang,

Nanjing Normal University, China

Meng Wang,

Northeast Normal University, China

*Correspondence:

Ming Jiang

jiangm@iga.ac.cn

Specialty section:

This article was submitted to

Hydrosphere,

a section of the journal

Frontiers in Earth Science

Received: 02 December 2021

Accepted: 24 December 2021

Published: 09 February 2022

Citation:

Cong Y, Zhang Z, Liu B, Chen Y, Li X, Jiang $M$ and Li M-H (2022) Resource Remobilization Efficiency Varies With Plant Growth Form but Not Between

Fens and Bogs.

Front. Earth Sci. 9:827721.

doi: 10.3389/feart.2021.827721

\section{Resource Remobilization Efficiency Varies With Plant Growth Form but Not Between Fens and Bogs}

\author{
Yu Cong ${ }^{1,2}$, Zhongsheng Zhang ${ }^{1,2}$, Bo Liu ${ }^{1}$, Yingyi Chen ${ }^{1}$, Xiao $\mathrm{Li}^{1}$, Ming Jiang ${ }^{1,2 *}$ and \\ Mai-He $L i^{3,4}$ \\ ${ }^{1}$ Key Laboratory of Wetland Ecology and Environment, Northeast Institute of Geography and Agricultural Ecology, Chinese \\ Academy of Sciences, Changchun, China, '2Jilin Provincial Joint Key Laboratory of Changbai Mountain Wetland and Ecology, \\ Changchun, China, ${ }^{3}$ Swiss Federal Institute for Forest, Snow and Landscape Research WSL, Zürich, Switzerland, ${ }^{4}$ Key \\ Laboratory of Geographical Processes and Ecological Security in Changbai Mountains, Ministry of Education, School of \\ Geographical Sciences, Northeast Normal University, Changchun, China
}

Resource resorption from senescing leaves is an important strategy for internal nutrient recycling in plants. However, our understanding of whether the responses of resource remobilization to mire types (fens vs. bogs) differ among various plant growth forms remains unclear. We thus assessed resource remobilization among various growth forms in fens and bogs in the Hani peatland in the Changbai Mountains, northeastern China. We analyzed and compared the concentrations of non-structural carbohydrates (NSCs), nitrogen $(\mathrm{N})$, phosphorus $(\mathrm{P})$, and potassium $(\mathrm{K})$ in leaves and roots collected in August (mid-season) and September (end-season), and calculated the resource remobilization efficiency (RRE) of four species belonging to four growth forms grown in both fens and bogs. The deciduous dwarf trees (Betula fruticosa) and perennial grass (Phragmites australis) had relative higher leaf RRE than the moss (Sphagnum magellanicum). Although leaf nutrient RRE did not differ between fens and bogs, the deciduous dwarf trees had a higher leaf NSC RRE in bogs than in fens, and the moss NSC RRE was lower in bogs than in fens. Our results suggest that reallocation of mobile carbohydrates seems to be more sensitive to the growth condition than nutrients $(N, P$, and $\mathrm{K}$ ) under nutrient-poor inhabits, which may be one of the reasons leading to nutrient limitation in peatlands.

\footnotetext{
Keywords: mires, non-structural carbohydrates, nitrogen, phosphorus, potassium, reallocation, storage, plant growth form
}

\section{INTRODUCTION}

Peatlands are usually classified into two categories: ombrogenous bogs and geogenous fens (Bridgham et al., 1996; Jonasson and Shaver, 1999). These peatlands types are characterized by high water tables, low nutrient availability, and dominant plant species (Aerts et al., 1999; Bridgham et al., 1996). The imbalance and shortage of nutrients can differ considerably between fens and bogs (Ohlson, 1995; Jonasson and Shaver, 1999), mainly due to the hydrological distinction (Waughman, 1980). Fens are fed by precipitation, mineral- and nutrient-rich surface water, and groundwater (Aerts \& Chapin, 1999), whereas bogs lack groundwater input and receive nutrients mainly from precipitation (Charman, 2002), leading to different growth forms that occur in fens and bogs. Fens are often dominated by deciduous shrubs or dwarf shrubs and graminoids (mainly Carex and 
Cladium species), while bogs are dominated by Sphagnum mosses and evergreen shrubs or dwarf shrubs and trees (Maimer et al., 1992; Bridgham et al., 1996). Previous studies have shown that plants in fens and bogs are often limited by nutrient availability (Charman, 2002; Wang et al., 2014; Li et al., 2019). This raises the question of how plants respond to low nutrient availability in fens and bogs.

Effective resource resorption from senescing leaves is an important strategy for internal nutrient recycling (Killingbeck, 1996), which reduces plants' dependence on external nutrient supply from the environment (Aerts and Chapin, 1999). It has been estimated that, in general, half of nitrogen $(\mathrm{N})$ and phosphorus (P) contained in mature leaves would be withdrawn during senescence (Aerts, 1996). Vergutz et al. (2012) calculated that the mean nutrient resorption efficiency was over $60 \%$ for $\mathrm{N}$ and $\mathrm{P}$ and $70 \%$ for $\mathrm{K}$ of global terrestrial plants. The patterns of resource remobilization differ among various growth forms. A large-scale study found that differences of leaf nutrient-use efficiency in plant growth forms are more important than differences in mire type (fen vs. bog) (Aerts et al., 1999). Greater allocation to storage in deciduous than in evergreen species reflects the lower opportunity cost in deciduous species that experience a more pronounced asynchrony of supply and demand (Chapin et al., 1990). For example, storage of carbohydrates is particularly important for deciduous species that do not have green tissues in early season and relay on carbon storage for regrowth (Epron et al., 2012). Similarly, Aerts (1996) found that nitrogen resorption efficiency was significantly higher in deciduous species and graminoids than in evergreen species and forbs, while $\mathrm{P}$ resorption efficiency did not differ between these growth forms. Yuan and Chen (2009) had observed consistent differences between deciduous and evergreen species. However, Vergutz et al. (2012) reported that graminoid had much higher nutrient resorption efficiency, due to the smaller non-leaf pools, leading to a greater need for nutrient resorption compared to other growth forms. Moreover, several studies highlighted that roots or rhizome played a crucial role as resource storage tissues of deciduous species and herbaceous plants (Granéli et al., 1992; Millard et al., 2001; Cong et al., 2019). In contrast, evergreen species directly retained resources in over-wintering leaves rather than recycled back to roots (Wyka et al., 2016).

Various relationships between nutrient availability and nutrient resorption were found. Some species growing in nutrient-poor habitats have higher resource remobilization efficiency (RRE) than those in moderate habitats (Pensa and Sellin, 2003; Yuan et al., 2005). A large-scale study found that bog species had a higher $\mathrm{P}$ use efficiency than fen species (Aerts et al., 1999). High RRE may help plants to obtain a competitive advantage in the infertile habitats (Pugnaire and Chapin, 1993). However, some evidence showed no major differences in nutrient resorption between plants in infertile and fertile soils (Aerts, 1996; Yuan and Chen, 2009). Hence, response of RRE to nutrient availability remains controversial.

In this study, we investigated and compared resource remobilization among various growth forms in fens and bogs in the Hani peatland in the Changbai Mountains. We measured tissue concentrations of non-structural carbohydrates (NSCs), N, $\mathrm{P}$, and $\mathrm{K}$ at the peak-growing season and at the end of growing season, and calculated and compared the RRE of species grown in both fens and bogs, to answer the following questions: (1) whether the RRE varies with growth forms and (2) whether the RRE differs between bogs and fens.

\section{MATERIALS AND METHODS}

\section{Study Sites}

The study was conducted at the Hani Peatland $\left(42^{\circ} 13^{\prime} \mathrm{N}\right.$, $126^{\circ} 31^{\prime} \mathrm{E}$ ) located in the west Changbai Mountain region in northeastern China. The area has a continental monsoon climate with a mean annual air temperature of $2.5-3.6^{\circ} \mathrm{C}(\mathrm{Bu}$ et al., 2011). The annual precipitation ranges from 757 to $930 \mathrm{~mm}$ (Li et al., 2019). The peatland has a mean peat depth of $4 \mathrm{~m}$; the deepest record was $9.6 \mathrm{~m}$ (Qiao, 1993). The peatland plants consist of dwarf trees (mainly Betula fruticosa Pall.), dwarf shrubs (mainly Rhododendron tomentosum Harmaja, and Vaccinium uliginosum L.), herbs [Carex lasiocarpa Ehrh., Phragmites australis (Clav.), Eriophorum polystachion L., and Smilacina japonica A. Gray], and peat mosses including Sphagnum magellanicum and S. palustre L. (Bu et al., 2017).

\section{Field Sampling}

To compare RRE patterns of plants growing in fens and bogs, four plant species that grow in both fens and bogs were selected. The four species included B. fruticosa Pall. (deciduous dwarf tree), $P$. australis (Clav.) (perennial grass), C. lasiocarpa Ehrh. (perennial grass), and $S$. magellanicum (moss). We selected five fens plots $(n=5)$ and four bogs plots $(n=4)$; within each plot, there were all the four species selected. We collected leaves and roots $(<0.5 \mathrm{~cm}$ in diameter) from six to eight individuals for each plant species within each plot and pooled them for a mixed leaf sample and root sample for each plot. However, for S. magellanicum, we collected branch leaves only, because it does not have proper roots. For leaf samples, mature and healthy leaves were collected on August 6, 2020 (mid-season), while only freshly yellow/fallen leaves were selected on September 16 (end-season), to minimize growth-form differences in leaf phenology among plant species. Also, to diminish the effects of diurnal temperature range and sunlight differences, all samples were collected at noon, placed in a cool box with ice, and transported immediately to the laboratory (Cong et al., 2019). Tissue samples were heated in a microwave oven at $600 \mathrm{~W}$ for $40 \mathrm{~s}$ to minimize the physiological activities, and dried at $65^{\circ} \mathrm{C}$ to a constant weight (Li et al., 2008). All samples were ground to powder with a ball mill (MM400, Retsch, Germany), and stored after being sealed with silica gel at $4^{\circ} \mathrm{C}$ prior to analyses.

\section{Analysis of NSC}

Dried plant material ( $30 \mathrm{mg}$ ) was put into a $10-\mathrm{ml}$ centrifuge tube and mixed with $5 \mathrm{ml}$ of $80 \%$ ethanol. The mixture was incubated at $80^{\circ} \mathrm{C}$ in a water shaker (SHA-C, Jintan Jingda Instrument Manufacturing Co., Ltd., Jintan, China) for $30 \mathrm{~min}$, cooled to ambient temperature, and then centrifuged at $4,000 \mathrm{rpm}$ for 
$10 \mathrm{~min}$. The precipitates were re-extracted twice with $80 \%$ ethanol to extract the soluble sugars ( $\mathrm{Li}$ et al., 2018). The ethanol-insoluble pellets were used for starch extraction, and the combined supernatants were saved for soluble sugars analysis by the anthrone method (Dubois et al., 1956). Glucose was used as a standard. Starch was extracted from the ethanol-insoluble residue placed at an $80^{\circ} \mathrm{C}$ water bath to remove the ethanol by evaporation. The ethanol-insoluble residues were boiled in $2 \mathrm{ml}$ of distilled water for $15 \mathrm{~min}$. After cooling to room temperature, $2 \mathrm{ml}$ of $9.2 \mathrm{M} \mathrm{HClO}_{4}$ was added to hydrolyze the starch for $15 \mathrm{~min}$ and $4 \mathrm{ml}$ of distilled water was added to the samples. The mixture was centrifuged at 4,000 rpm for $10 \mathrm{~min}$. Thereafter, the solid residues were extracted once more with $2 \mathrm{ml}$ of $4.6 \mathrm{M}$ $\mathrm{HClO}_{4}$. Soluble sugars and starch concentrations were both determined using a spectrophotometer (TU-1810, Beijing Purkinje General Instrument Co., Ltd., Beijing, China) at $620 \mathrm{~nm}$ (Wang et al., 2018). Starch concentration was calculated by the glucose concentration by a conversion factor of 0.9. The soluble sugars, starch, and NSC concentrations were expressed on a dry matter basis (\% d.m.).

\section{Analysis of Nitrogen, Phosphorus, and Potassium}

Oven-dried plant samples $(0.1 \mathrm{~g})$ were digested in concentrated $\mathrm{H}_{2} \mathrm{SO}_{4}$ and $\mathrm{H}_{2} \mathrm{O}_{2}$ (Parkinson and Allen, 1975). Nitrogen (N) concentration was then determined with an automatic chemical analyzer (SmartChem 140, AMS-Alliance Instruments, Rome, Italy), using the indophenol blue colorimetric method. Phosphorus (P) was measured colorimetrically by the ammonium molybdate-ascorbic acid method (Murphy and Riley, 1962) on a spectrophotometer (TU-1810, Beijing Purkinje General Instrument Co., Ltd., Beijing, China). Potassium (K) concentration was determined on a flame photometer (FP6410, Shanghai Precise Scientific Instrument Co., Ltd., Shanghai, China).

\section{METHODS FOR RESOURCE REMOBILIZATION EVALUATION}

Remobilization efficiency $(R)$ was determined by the resource concentrations at the mid-season and at the end of growing season. Therefore, remobilization efficiency (\%) of each tissue was calculated according to Eq. 1 (Killingbeck, 1996):

$$
R \%=\frac{C_{s}-C_{a}}{C_{a}} \times 100 \%=\left(\frac{C_{s}}{C_{a}}-1\right) \times 100 \%
$$

where $C_{s}$ and $C_{a}$ represent the concentrations of NSC, N, P, or K of each tissue at the end-season (September) and at the midseason (August), respectively. A negative $R$ value $\left(C_{s}<C_{a}\right)$ indicates resource transfer from that tissue, while a positive value $\left(C_{s}>C_{a}\right)$ indicates resource accumulation in that tissue. A smaller negative $R$ value suggests higher remobilization efficiency, whereas a larger positive $R$ value suggests higher accumulation efficiency.

\section{Data Analysis}

We defined NSC as the sum of soluble sugars and starch within each sample (Li et al., 2001; Li et al., 2002; Zhu et al., 2012). Data of NSC, soluble sugars, starch, and nutrients (i.e., N, P, and K) were confirmed for normality by Kolmogorov-Smirnov tests before statistical analysis. The above-mentioned data were analyzed using three-way ANOVAs with mire types, species, and time as fixed factors. Within each sampling time, two-way ANOVAs, with mire types and species as factors, were repeatedly performed to detect differences in parameters studied. Three-way ANOVAs with main factors of mire types, species, and tissue types were performed to test the trends in the remobilization efficiency of NSC, N, P, and K. Overall differences between fens and bogs species were analyzed using independent $t$-test.

\section{RESULTS}

\section{Plant NSCs and Nutrients in Bogs and Fens}

Leaf concentrations of NSCs (i.e., soluble sugars and starch) and nutrients (i.e., $\mathrm{N}, \mathrm{P}$, and $\mathrm{K}$ ) varied significantly with species and sampling time (Table 1), while only leaf soluble sugars and $\mathrm{NSC}_{\mathrm{T}}$ were significantly affected by mire types (Table 1). Species interacted with sampling time to significantly influence leaf soluble sugars, $\mathrm{NSC}_{\mathrm{T}}$, and nutrients, whereas mire types interacted with species to affect leaf $\mathrm{K}$ and with sampling time to influence leaf sugars and $\mathrm{NSC}_{\mathrm{T}}$ (Table 1). Within the August sampling date, leaf NSCs (except for leaf starch with a $p=0.081$ ) and nutrients varied significantly with species (Table 2; Figures 1A-C, Figures $\mathbf{2 A - C}$ ), while only leaf sugars, $\mathrm{NSC}_{\mathrm{T}}$ and $\mathrm{K}$ significantly differed between fens and bogs (Table 2), showing higher levels in bogs than in fens for all the four species (Figures 1A,C, and Figure 2C). At the end-season in September, leaf NSCs and nutrients differed among species only but did not change with mire type (Table 3; Figures 1A-C, Figures 2A-C). Generally, B. fruticosa (S1) had the highest level of NSCs and S. magellanicum (S4) showed the lowest levels of leaf NSCs in August (Figures 1A-C), whereas P. australis (S2) had the highest leaf nutrient levels and S. magellanicum (S4) showed the lowest leaf nutrient levels in August (Figures 2A-C).

Root concentrations of NSCs and nutrients (except for root $\mathrm{P}$ with a $p=0.762$ ) varied significantly with mire types and species (Table 1), whereas root soluble sugars, $\mathrm{NSC}_{\mathrm{T}}, \mathrm{N}$, and $\mathrm{P}$ were significantly affected by sampling time (Table 1). Mire types interacted with sampling time to did not differ for all parameters, while species interacted with mire types to significantly influence root starch, $\mathrm{N}$, and $\mathrm{P}$ and with sampling time to influence root sugars, $\mathrm{NSC}_{\mathrm{T}}, \mathrm{N}$, and $\mathrm{P}$ (Table 1). Within the August sampling date, root NSCs and nutrients varied significantly with species (Table 2; Figures 1D-F, Figures 2D-F), while only root sugars, $\mathrm{NSC}_{\mathrm{T}}$, and $\mathrm{N}$ significantly differed between fens and bogs (Table 2), showing higher $\mathrm{NSC}_{\mathrm{T}}$ and $\mathrm{K}$ in bogs than in fens for all the 3 species (Figures 1D-F, and Figure 2F), but lower $\mathrm{N}$ and $\mathrm{K}$ in bogs than in fens for P. australis (S2) (Figures 2D,E). At the end-season in September, root NSC $_{\mathrm{T}}$ (except for root starch with a $p=0.804$ ) and nutrients differed among species, while only root starch, $\mathrm{NSC}_{\mathrm{T}}$, and $\mathrm{N}$ significantly differed between fens and 
TABLE 1 | Effects of mire types, species, sampling time, and their interactions on concentrations of NSCs (i.e., sugars, starch, and NSC $\mathrm{T}$ ) and nutrients (i.e., N, P, and K) in plant leaves and roots, tested with three-way nested ANOVAs. $F$ and $p$ values are given.

\begin{tabular}{|c|c|c|c|c|c|c|c|c|c|c|c|c|c|}
\hline \multirow[t]{2}{*}{ Factors } & \multirow[t]{2}{*}{ Df } & \multicolumn{2}{|c|}{ Soluble sugars } & \multicolumn{2}{|c|}{ Starch } & \multicolumn{2}{|c|}{$\mathrm{NSC}_{\mathbf{T}}$} & \multicolumn{2}{|c|}{ Nitrogen (N) } & \multicolumn{2}{|c|}{ Phosphorus (P) } & \multicolumn{2}{|c|}{ Potassium (K) } \\
\hline & & $\boldsymbol{F}$ & $p$ & $\boldsymbol{F}$ & $p$ & $\boldsymbol{F}$ & $p$ & $\boldsymbol{F}$ & $p$ & $\boldsymbol{F}$ & $p$ & $\boldsymbol{F}$ & $p$ \\
\hline \multicolumn{14}{|l|}{ Leaves } \\
\hline Mire types (M) & 1 & 9.526 & 0.003 & 3.293 & 0.075 & 11.092 & 0.002 & 0.052 & 0.821 & 0.396 & 0.532 & 3.825 & 0.055 \\
\hline Species (S) & 3 & 98.887 & $<0.001$ & 7.13 & $<0.001$ & 113.638 & $<0.001$ & 129.768 & $<0.001$ & 12.839 & $<0.001$ & 72.329 & $<0.001$ \\
\hline Time $(T)$ & 1 & 19.896 & $<0.001$ & 8.132 & 0.006 & 30.214 & $<0.001$ & 180.551 & $<0.001$ & 194.279 & $<0.001$ & 169.386 & $<0.001$ \\
\hline$M \times S$ & 3 & 1.146 & 0.338 & 1.327 & 0.275 & 0.414 & 0.743 & 0.201 & 0.895 & 0.993 & 0.403 & 2.884 & 0.044 \\
\hline$M \times T$ & 1 & 9.536 & 0.003 & $<0.001$ & 0.986 & 8.038 & 0.006 & 0.568 & 0.454 & 0.048 & 0.828 & 3.115 & 0.083 \\
\hline $\mathrm{S} \times \mathrm{T}$ & 3 & 29.359 & $<0.001$ & 0.037 & 0.991 & 28.384 & $<0.001$ & 45.623 & $<0.001$ & 37.713 & $<0.001$ & 53.595 & $<0.001$ \\
\hline $\mathrm{M} \times \mathrm{S} \times \mathrm{T}$ & 3 & 2.192 & 0.099 & 0.964 & 0.416 & 2.516 & 0.067 & 1.224 & 0.309 & 0.659 & 0.581 & 3.039 & 0.036 \\
\hline \multicolumn{14}{|l|}{ Roots } \\
\hline Mire types (M) & 1 & 13.27 & 0.001 & 9.729 & 0.003 & 17.313 & $<0.001$ & 11.917 & 0.001 & 0.093 & 0.762 & 6.731 & 0.013 \\
\hline Species (S) & 3 & 14.864 & $<0.001$ & 4.631 & 0.015 & 14.873 & $<0.001$ & 221.578 & $<0.001$ & 44.162 & $<0.001$ & 63.949 & $<0.001$ \\
\hline Time $(T)$ & 1 & 37.382 & $<0.001$ & 0.306 & 0.583 & 31.384 & $<0.001$ & 78.82 & $<0.001$ & 30.189 & $<0.001$ & 2.387 & 0.13 \\
\hline$M \times S$ & 3 & 1.662 & 0.202 & 4.15 & 0.023 & 2.89 & 0.067 & 11.404 & $<0.001$ & 3.766 & 0.032 & 3.009 & 0.06 \\
\hline$M \times T$ & 1 & 2.507 & 0.121 & 1.43 & 0.238 & 1.114 & 0.297 & 0.605 & 0.441 & 0.257 & 0.615 & 0.019 & 0.892 \\
\hline$S \times T$ & 3 & 7.325 & 0.002 & 2.023 & 0.145 & 7.968 & 0.001 & 104.713 & $<0.001$ & 24.677 & $<0.001$ & 1.372 & 0.265 \\
\hline $\mathrm{M} \times \mathrm{S} \times \mathrm{T}$ & 3 & 2.428 & 0.1 & 1.941 & 0.156 & 0.978 & 0.384 & 1.045 & 0.361 & 2.472 & 0.097 & 1.498 & 0.235 \\
\hline
\end{tabular}

Bold values highlight significant effects at $\mathrm{p}<0.05$.

TABLE 2 | Effects of mire types, species, and their interactions on concentrations of NSCs (i.e., sugars, starch, and NSC $\mathrm{T}$ ) and nutrients (i.e., N, P, and K) in plant leaves and roots in August, tested with two-way nested ANOVAs. $F$ and $p$ values are given.

\begin{tabular}{|c|c|c|c|c|c|c|c|c|c|c|c|c|c|}
\hline \multirow[t]{2}{*}{ Factors } & \multirow[t]{2}{*}{ Df } & \multicolumn{2}{|c|}{ Soluble sugars } & \multicolumn{2}{|c|}{ Starch } & \multicolumn{2}{|c|}{$\mathrm{NSC}_{\mathbf{T}}$} & \multicolumn{2}{|c|}{ Nitrogen (N) } & \multicolumn{2}{|c|}{ Phosphorus (P) } & \multicolumn{2}{|c|}{ Potassium (K) } \\
\hline & & $\boldsymbol{F}$ & $p$ & $F$ & $p$ & $\boldsymbol{F}$ & $p$ & $\boldsymbol{F}$ & $p$ & $\boldsymbol{F}$ & $p$ & $F$ & $p$ \\
\hline \multicolumn{14}{|l|}{ Leaves } \\
\hline Mire types (M) & 1 & 14.379 & 0.001 & 1.083 & 0.307 & 14.416 & 0.001 & 0.666 & 0.421 & 0.358 & 0.555 & 5.59 & 0.025 \\
\hline Species (S) & 3 & 69.478 & $<0.001$ & 2.493 & 0.081 & 76.86 & $<0.001$ & 225.38 & $<0.001$ & 44.569 & $<0.001$ & 83.016 & $<0.001$ \\
\hline$M \times S$ & 3 & 1.625 & 0.206 & 1.205 & 0.326 & 1.259 & 0.307 & 1.531 & 0.228 & 1.123 & 0.357 & 4.349 & 0.012 \\
\hline \multicolumn{14}{|l|}{ Roots } \\
\hline Mire types (M) & 1 & 11.149 & 0.003 & 2.729 & 0.113 & 10.079 & 0.005 & 7.433 & 0.013 & 0 & 0.992 & 2.995 & 0.098 \\
\hline Species (S) & 2 & 12.232 & $<0.001$ & 9.387 & 0.001 & 12.57 & $<0.001$ & 259.686 & $<0.001$ & 32.711 & $<0.001$ & 30.646 & $<0.001$ \\
\hline$M \times S$ & 2 & 2.029 & 0.156 & 6.477 & 0.006 & 1.611 & 0.223 & 7.835 & 0.003 & 4.78 & 0.019 & 0.85 & 0.442 \\
\hline
\end{tabular}

Bold values highlight significant effects at $\mathrm{p}<0.05$.

bogs (Table 3; Figures 1D-F, Figures 2D-F). Species interacted with mire types to significantly influence root $\mathrm{N}$ and $\mathrm{K}$ (Table 3 ). Generally, B. fruticosa (S1) had the highest level of $\mathrm{NSC}_{\mathrm{T}}$ in August (Figures 1D-F), whereas P. australis (S2) had the highest root nutrient levels and $B$. fruticosa (S1) showed the lowest root nutrient levels in August (Figures 2D-F).

\section{Carbohydrate and Nutrients Remobilization}

Mire types and mire types $\times$ species interaction only significantly affected the remobilization efficiency of NSC (Table 4). The NSC remobilization efficiency in $B$. fruticosa (S1) leaves was significantly higher in bogs than in fens (Figure 3A). In contrast, S. magellanicum (S4) leaves had lower NSC remobilization efficiency in bogs compared with fens (Figure 3A). Both species and tissue types, and their interaction had significant effects on NSC and nutrient remobilization efficiency (Table 4). At the end of the growing season, leaves resources in four species were reallocated and even for NSC accumulation in C. lasiocarpa (S3) and S. magellanicum (S4) (Figures 3A-D). However, roots accumulated NSC, but reallocated $\mathrm{N}, \mathrm{P}$, and $\mathrm{K}$ to other tissues, except for an $\mathrm{N}$ accumulation in C. lasiocarpa (S3) (Figures 3E-H). Generally, leaves resources remobilization efficiency were highest in $P$. australis (S2) and intermediate in B. fruticosa (S1) (Figures 3A-D). While B. fruticosa (S1) had the lowest root NSC remobilization efficiency and $P$. australis (S2) had the highest RRE (Figure 3E).

\section{DISCUSSION}

\section{Growth Form-Dependent Reallocation of Mobile Carbohydrates and Nutrients}

At the end of growing season, mobile carbohydrates translocated from senescing leaves (Figure 3A), whereas NSCs were stored in roots (Figure 3E). P. australis and B. fruticosa leaves reallocated NSC to roots (Figures 3A,E), leading to decreased leaf NSC concentrations (Figure 1A) but increased root concentrations (Figure 1D), which indicated that roots were the main NSC storage tissue in these two species. Our results supported the view 


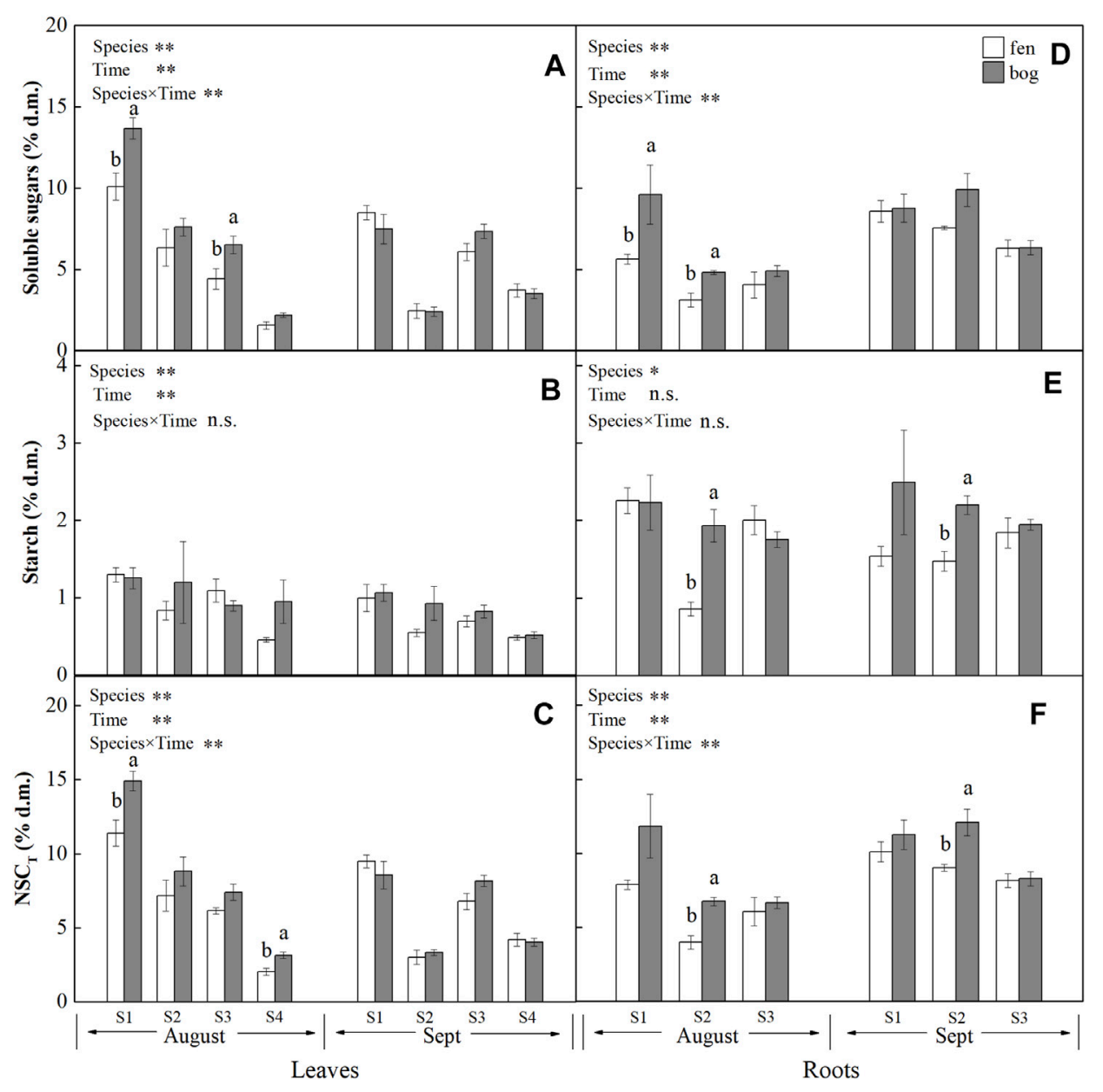

FIGURE 1 | Concentrations (mean \pm SE; \% of dry matter) of soluble sugars, starch, and NSC $\mathrm{T}$ in leaves and roots of plants grown in fens $(n=5)$ and bogs $(n=4)$ in the mid-season and end-season. Different lowercase letters display significant differences between fens and bogs for each species within each time, tested with $t$-test ( $p$ < 0.05). S1-S4 represent Betula fruticosa Pall., Phragmites australis (Clav.), Carex lasiocarpa Ehrh., and Sphagnum magellanicum, respectively.

that leaf carbohydrates recycle from leaves to storage tissue at leaf abscission in perennial plants (Chapin et al., 1990; Cong et al., 2018), which is most likely associated with the storage of NSC to ensure winter survival (Tixier et al., 2020) and support new growth after dormancy (Yan et al., 2016). In contrast, $S$. magellanicum directly retain NSC in leaves rather than translocate carbon compounds to roots (Figure 1A). As Sphagnum mosses have no anatomically specialized internal conducting tissue, it has long been believed that mosses do not have nutrient remobilization processes (Aerts et al., 1999). However, as suggested previously by Rydin et al. (1989), mobile carbohydrates of Sphagnum papillosum were translocated from older parts to the capitulum. Our results confirmed internal redistribution of carbon compounds in S. magellanicum, and carbohydrates were stored in leaves due to no real roots for transport.

We found a growth-form-dependent NSC remobilization efficiency (Table 4). The result of the observed differences among species was that $P$. australis had the highest leaf NSC remobilization efficiency followed by the deciduous tree $B$. fruticosa (S2) (Figure 3A). P. australis also had the highest root remobilization efficiency followed by $C$. lasiocarpa (Figure 3E). The efficiency of NSC relocation from senescing leaves ranged from $55 \%$ to $60 \%$ in P. australis (Figure 3A), which is much higher than $28 \%$ reported by Gessner (2001) for the same species (Chapin et al., 1990; Gessner, 2001). Higher leaf NSC remobilization efficiency indicated that a major portion of carbohydrates was translocated to rhizome and roots, necessarily resulting in greater efficiency of $P$. australis roots. To resist environmental stress, such as deep water or late season frost, rhizome carbohydrates storage was much larger than needed to ensure establishment of spring shoots for Phragmites (Granéli et al., 1992). Intermediate leaf NSC remobilization efficiency of $B$. fruticosa should be associated with leaf traits; deciduous tree species produce new leaves at a low cost, rather than store carbohydrates with a high cost (Dickson, 1989), which might be due to the frequent alternation between new leaves and defoliation.

In spite of the different growth forms, nutrients ( $\mathrm{N}, \mathrm{P}$, and $\mathrm{K}$ ) were all remobilized from senescing leaves (Figures 3B-D), 


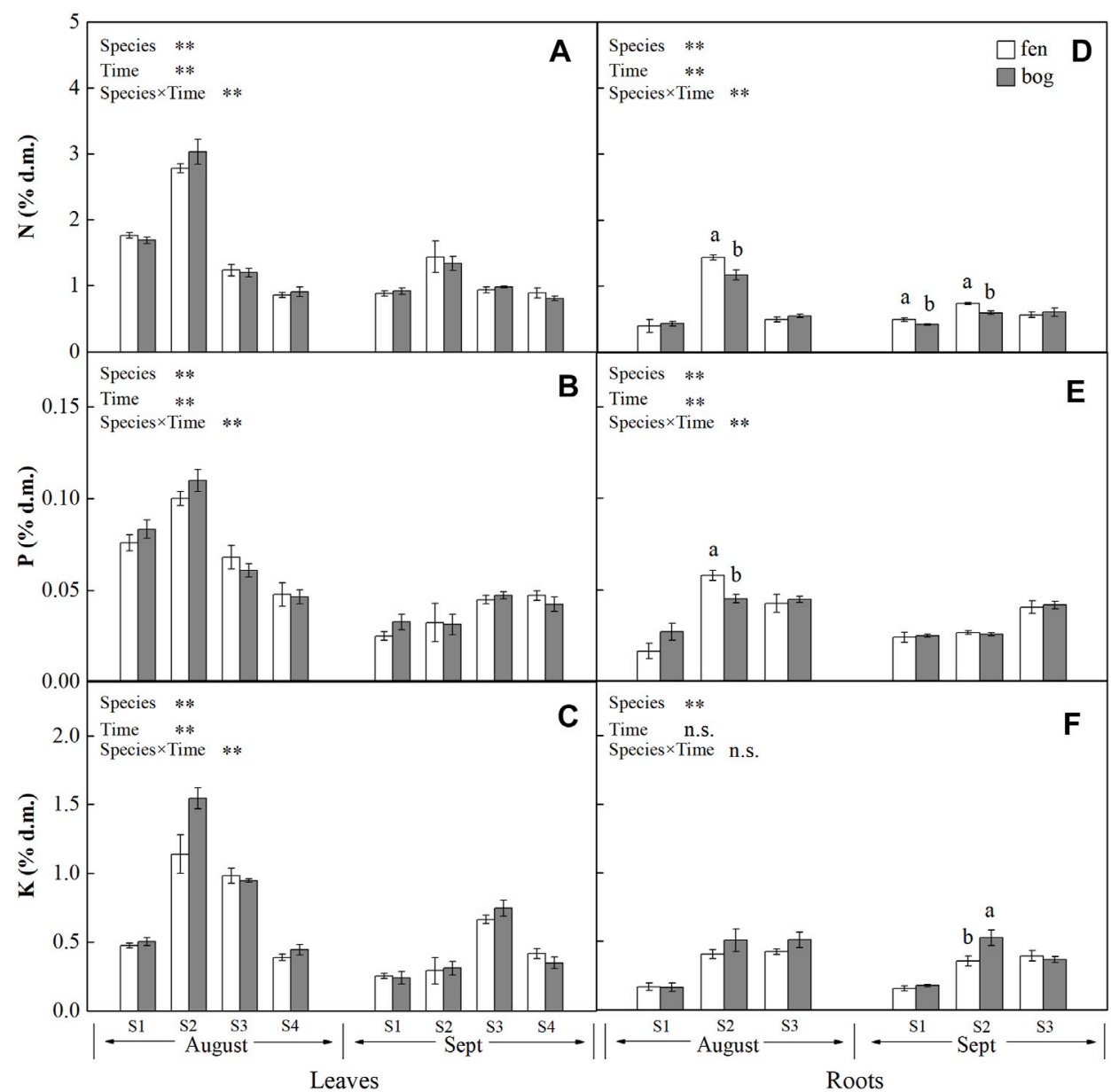

FIGURE 2 Concentrations (mean \pm SE; \% of dry matter) of N, P, and K in leaves and roots of plants grown in fens ( $n=5)$ and bogs ( $n=4)$ in the mid-season and end-season. Different lowercase letters display significant differences between fens and bogs for each species within each time, tested with $t$-test $(p<$ 0.05). S1-S4 represent B. fruticosa, P. australis, C. lasiocarpa, and S. magellanicum, respectively.

TABLE 3 | Effects of mire types, species, and their interactions on concentrations of NSCs (i.e., sugars, starch, and NSC ) and nutrients (i.e., N, P, and K) in plant leaves and roots in September, tested with two-way nested ANOVAs. $F$ and $p$ values are given.

\begin{tabular}{|c|c|c|c|c|c|c|c|c|c|c|c|c|c|}
\hline \multirow[t]{2}{*}{ Factors } & \multirow[t]{2}{*}{ Df } & \multicolumn{2}{|c|}{ Soluble sugars } & \multicolumn{2}{|c|}{ Starch } & \multicolumn{2}{|c|}{$\mathrm{NSC}_{\mathbf{T}}$} & \multicolumn{2}{|c|}{ Nitrogen (N) } & \multicolumn{2}{|c|}{ Phosphorus (P) } & \multicolumn{2}{|c|}{ Potassium (K) } \\
\hline & & $\boldsymbol{F}$ & $p$ & $\boldsymbol{F}$ & $p$ & $\boldsymbol{F}$ & $p$ & $\boldsymbol{F}$ & $p$ & $\boldsymbol{F}$ & $p$ & $\boldsymbol{F}$ & $p$ \\
\hline \multicolumn{14}{|l|}{ Leaves } \\
\hline Mire types (M) & 1 & 0 & 0.999 & 3.586 & 0.069 & 0.18 & 0.675 & 0.108 & 0.745 & 0.085 & 0.773 & 0.024 & 0.878 \\
\hline Species (S) & 3 & 53.596 & $<0.001$ & 7.335 & 0.001 & 59.697 & $<0.001$ & 9.849 & $<0.001$ & 5.81 & 0.003 & 30.361 & $<0.001$ \\
\hline$M \times S$ & 3 & 1.755 & 0.179 & 0.939 & 0.435 & 1.863 & 0.159 & 0.25 & 0.861 & 0.526 & 0.668 & 0.707 & 0.556 \\
\hline \multicolumn{14}{|l|}{ Roots } \\
\hline Mire types (M) & 1 & 2.736 & 0.113 & 7.041 & 0.015 & 7.417 & 0.013 & 4.406 & 0.048 & 0.034 & 0.856 & 4 & 0.059 \\
\hline Species (S) & 2 & 9.297 & 0.001 & 0.22 & 0.804 & 9.033 & 0.001 & 20.142 & $<0.001$ & 33.57 & $<0.001$ & 35.98 & $<0.001$ \\
\hline$M \times S$ & 2 & 2.071 & 0.151 & 1.287 & 0.297 & 2.606 & 0.098 & 3.851 & 0.038 & 0.131 & 0.878 & 4.567 & 0.023 \\
\hline
\end{tabular}

Bold values highlight significant effects at $\mathrm{p}<0.05$.

supporting that nutrient remobilization is an important strategy employed by plants to conserve nutrients (Aerts, 1996; Chapin, 1980) and leaves play a primary role in nutrient remobilization (Eckstein et al., 1998). About half of $\mathrm{N}$ was recycled from senescing leaves in $P$. australis and deciduous trees
(Figure 1B). These findings agreed with general perennials of Aerts (1996), who found that $\mathrm{N}$ resorption efficiency varied approximately $50 \%$ across different species or growth forms. However, N remobilization efficiency of C. lasiocarpa was $20 \%$ (Figure 3B), which is much lower than that value reported by 
TABLE 4 | Effects of mire types, species, tissue types, and their interactions on resources remobilization between plant leaves and roots, tested with three-way nested ANOVAs. $F$ and $p$ values are given. $R$ refers to remobilization efficiency.

\begin{tabular}{|c|c|c|c|c|c|c|c|c|c|}
\hline \multirow[t]{2}{*}{ Factors } & \multirow[t]{2}{*}{ Df } & \multicolumn{2}{|c|}{ R NSC } & \multicolumn{2}{|c|}{ R Nitrogen } & \multicolumn{2}{|c|}{ R Phosphorus } & \multicolumn{2}{|c|}{ R Potassium } \\
\hline & & $\boldsymbol{F}$ & $p$ & $\boldsymbol{F}$ & $p$ & $\boldsymbol{F}$ & $p$ & $\boldsymbol{F}$ & $p$ \\
\hline Mire types (M) & 1 & 22.321 & $<0.001$ & 0.837 & 0.365 & 0.101 & 0.751 & 0.041 & 0.84 \\
\hline Species (S) & 3 & 28.767 & $<0.001$ & 36.539 & $<0.001$ & 33.346 & $<0.001$ & 8.184 & $<0.001$ \\
\hline Tissue types (T) & 1 & 92.608 & $<0.001$ & 38.7 & $<0.001$ & 51.364 & $<0.001$ & 44.075 & $<0.001$ \\
\hline$M \times S$ & 3 & 4.357 & 0.008 & 0.541 & 0.657 & 0.624 & 0.603 & 0.567 & 0.639 \\
\hline$M \times T$ & 1 & 1.853 & 0.18 & 0.138 & 0.712 & 0.235 & 0.63 & 0.454 & 0.504 \\
\hline$S \times T$ & 2 & 29.653 & $<0.001$ & 7.822 & 0.001 & 8.848 & 0.001 & 7.154 & 0.002 \\
\hline$M \times S \times T$ & 2 & 0.9 & 0.413 & 0.398 & 0.674 & 0.859 & 0.43 & 1.833 & 0.171 \\
\hline
\end{tabular}

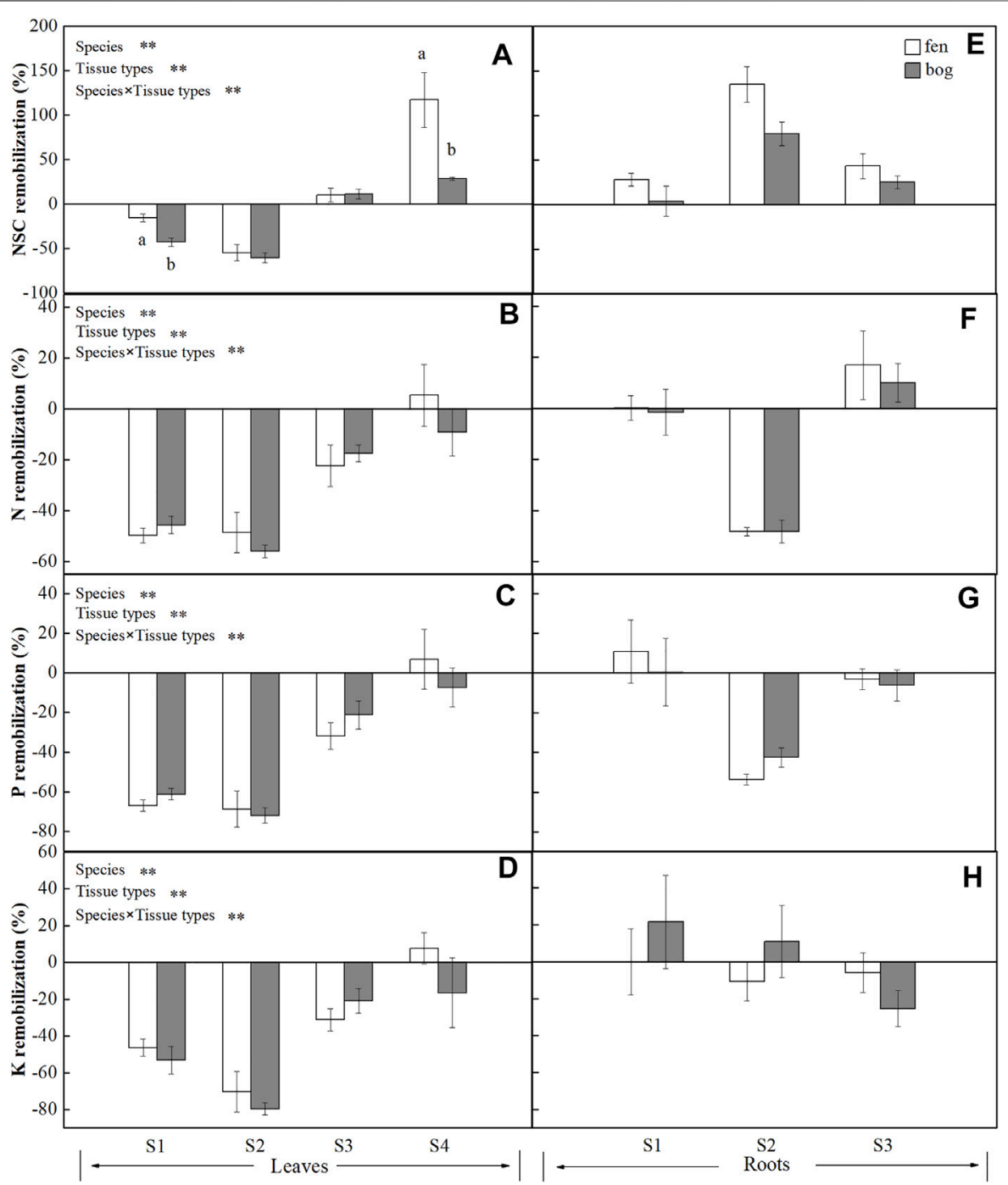

FIGURE 3 |Remobilization efficiency (mean \pm SE; \% of dry matter) of NSC, N, P, and K in leaves and roots of plants grown in fens $(n=5)$ and bogs $(n=4)$. Different lowercase letters display significant differences between fens and bogs for each species within each time, tested with $t$-test $(p<0.05)$. $\$ 1-S 4$ represent $B$. fruticosa, $P$. australis, C. lasiocarpa, and S. magellanicum, respectively. 
Aerts (1996) for graminoids (mean 59\%). Similarly, our results showed that $\mathrm{P}$ remobilization efficiency for $B$. fruticose and $P$. australis were comparable to the value $(64.9 \%)$ reported by Vergutz et al. (2012) (Figure 3C). However, leaves had lower resorption efficiency for K (4-50\%), except for P. australis (mean 75\%) (Vergutz et al., 2012) (Figure 3D). In addition, $\mathrm{N}$ was only resorbed from leaves of $C$. lasiocarpa and stored in roots (Figure 3F), as nitrogen stored in specific tissue with an individual species due to leaf habit (Millard and Grelet, 2010). As we have already seen, however, there were significant differences in leaf nutrient efficiency between growth forms (Table 4). Leaf nutrient remobilization efficiency was much higher in deciduous tree and herbs compared with moss (Figures 3B-D). Thus, these would suggest that high nutrient remobilization from leaves prior to senescence is characteristic for most species (Aerts, 1996), whereas Sphagnum mosses have lower nutrient remobilization efficiency, probably due to their adaptation to nutrient-poor habitats. Previous studies indicated that moss species were highly tolerant to nutrient-poor inhabits (Aerts et al., 1999; Turetsky et al., 2012), even Li et al. (2019) demonstrated that long-term application of nitrogen did not increase but decreased the growth of Sphagnum mosses, implying the reasons of lower nutrient remobilization efficiency of Sphagnum mosses.

\section{Effects of Fens and Bogs on Plant Resource Reallocation}

We did not find differences in leaf nutrient remobilization efficiency between fens and bogs (Table 4; Figures 3B-D); this result may be caused by the similar habitat characteristics dominated by high water level for both fens and bogs. A largescale analysis indicated that nutrient resorption did not differ between fens and bogs but varied with species or/and growth form (Aerts et al., 1999). Nevertheless, Bridgham et al. (1995) proposed that nutrient remobilization efficiency can be higher at low nutrient availability, representing an important adaptation to infertile habitats (Dissanayaka et al., 2017). For nutrient concentration in mature leaves, there were no differences in leaf nutrient concentrations between fens and bogs (Table 2; Figures 2A-C). This finding partly agreed with the conclusions of Aerts et al. (1999), who proposed that clear differences between fens and bogs species occurred in leaves' $\mathrm{P}$ concentrations, but not in leaves' $\mathrm{N}$ concentrations. However, there were no differences in nutrient remobilization of fine roots between fens and bogs (Table 4; Figures 3F-H). At the end of growing season, $\mathrm{N}$ concentrations of fine roots were significantly lower in $P$. australis and B. fruticosa in fens than in bogs (Figure 2D). No such pattern was found for $\mathrm{P}$ and $\mathrm{K}$ in fine roots (Figures $\mathbf{2 F}, \mathbf{G})$. These results suggested that $\mathrm{N}$ is the limiting mineral nutrient for Phragmites and deciduous tree, which also agreed with investigation on Phragmites in Sweden (Granéli et al., 1992).

We observed higher NSC remobilization efficiency and carbohydrates concentration of $B$. fruticosa leaves in bogs than in fens (Table 1, 4; Figures 1C, 3A). Thus, there are indications that translocation of non-structural carbon seems to be more important under nutrient-poor inhabits than translocation of nutrients $(\mathrm{N}, \mathrm{P}$, and $\mathrm{K})$, suggesting that the species were limited more by carbon supply than by recycling of nutrients (Chapin et al., 1990). The availability of carbohydrates is strictly dependent on and linked to the growth of leaves and shoots, the allocation of carbohydrates being determined by resource availability, growth capacity, and maintenance requirement (Marchi et al., 2007). Many studies have demonstrated that the translocation of carbohydrates from leaves can be unloaded to storage tissues that reload to support new leaf and shoot growth in next spring (Marchi et al., 2005a; Marchi et al., 2005b; Cong et al., 2018; Cong et al., 2019). Larger NSC remobilization in bogs than in fens reflected that deciduous trees adapted to nutrient-poor inhabits may resorb more carbohydrates from the senescing leaves and have greater dependence on carbohydrate remobilization. Similarly, although tissue NSC remobilization efficiency did not differ for Phragmites between fens and bogs (Figures 3A,E), root starch and NSC concentrations of Phragmites were higher in bogs than in fens at the end-season (Figures 1E,F). The starch and NSC concentrations of roots increased in bogs, which may enhance the ability of Phragmites to adapt to winter environmental changes (i.e., low nutrient and cold temperature) (Sheen et al., 1999), because soluble carbon components participate in cell osmotic regulation and prevent intracellular ice formation by lowering the freezing point of the cytoplasm (Morin et al., 2007). Furthermore, Granéli et al. (1992) proposed that the rhizome of Phragmites stored excess carbohydrates. Since some carbohydrate stores may become inaccessible to the plant with time due to a winter rhizome mortality of approximately 30\% (Granéli et al., 1992), carbohydrates remaining in dead cells cannot be retrieved (Ziegler, 1964). However, Sphagnum leaves had lower NSC remobilization efficiency in bogs, showing that Sphagnum mosses from nutrient-poor habitats have not adapted to oligotrophic environments by having a high NSC remobilization efficiency.

\section{CONCLUSION}

Our study clearly indicated that mobile carbohydrates and nutrients $(\mathrm{N}, \mathrm{P}$, and $\mathrm{K})$ in four plant species (i.e., four growth forms) grown in both fens and bogs were reallocated from leaves to storage tissues at the end of the growing season. The NSCs and nutrient remobilization efficiency differ among different growth forms. Deciduous dwarf trees (B. fruticosa) and perennial grass ( $P$. australis) had relative higher leaf resource remobilization efficiency, and moss ( $S$. magellanicum) showed lower leaf nutrient remobilization efficiency. Differences in resource remobilization among plant growth forms seem to be related to different strategies in utilizing resources (Chapin et al., 1990). We also found that leaf nutrient remobilization efficiency did not differ between fens and bogs. Overall, our results suggest that reallocation of mobile carbohydrates seems to be more sensitive to the growth condition than nutrients $(\mathrm{N}, \mathrm{P}$, and $\mathrm{K}$ ) under nutrient-poor inhabits, which may be one of the reasons leading to nutrient limitation in peatlands. 


\section{DATA AVAILABILITY STATEMENT}

The raw data supporting the conclusion of this article will be made available by the authors, without undue reservation.

\section{AUTHOR CONTRIBUTIONS}

$\mathrm{MJ}$ and $\mathrm{ZZ}$ contributed to conception. M-HL, ZZ, and $\mathrm{YuC}$ designed the experiment. YuC, $\mathrm{YiC}$, and $\mathrm{XL}$ performed the research. $\mathrm{YuC}$ analyzed the data and wrote the manuscript. $\mathrm{M}-\mathrm{HL}$ commented and revised the manuscript.

\section{REFERENCES}

Aerts, R., and Chapin, F. S. (1999). "The Mineral Nutrition of Wild Plants Revisited: A Re-evaluation of Processes and Patterns," in Advances in Ecological Research. Editors A. H. Fitter and D. G. Raffaelli (Academic Press), 1-67. doi:10.1016/s0065-2504(08)60016-1

Aerts, R. (1996). Nutrient Resorption from Senescing Leaves of Perennials: Are There General Patterns. J. Ecol. 84 (4), 597-608. doi:10.2307/2261481

Aerts, R., Verhoeven, J. T. A., and Whigham, D. F. (1999). Plant-mediated Controls on Nutrient Cycling in Temperate Fens and Bogs. Ecology 80 (7), 2170-2181. doi:10.1890/0012-9658(1999)080[2170:pmconc]2.0.co;2

Bridgham, S. D., Pastor, J., Janssens, J. A., Chapin, C., and Malterer, T. J. (1996). Multiple Limiting Gradients in Peatlands: A Call for a New Paradigm. Wetlands 16 (1), 45-65. doi:10.1007/bf03160645

Bridgham, S. D., Pastor, J., McClaugherty, C. A., and Richardson, C. J. (1995). Nutrient-Use Efficiency: A Litterfall Index, a Model, and a Test along a Nutrient-Availability Gradient in North Carolina Peatlands. The Am. Naturalist 145 (1), 1-21. doi:10.1086/285725

$\mathrm{Bu}, \mathrm{Z}$.-J., Rydin, H., and Chen, X. (2011). Direct and Interaction-Mediated Effects of Environmental Changes on Peatland Bryophytes. Oecologia 166 (2), 555-563. doi:10.1007/s00442-010-1880-1

Bu, Z. J., Sundberg, S., Feng, L., Li, H. K., Zhao, H. Y., and Li, H. C. (2017). The Methuselah of Plant Diaspores: Sphagnum Spores Can Survive in Nature for Centuries. New Phytol. 214 (4), 1398-1402. doi:10.1111/nph.14575

Chapin, F. S., Schulze, E., and Mooney, H. A. (1990). The Ecology and Economics of Storage in Plants. Annu. Rev. Ecol. Syst. 21, 423-447. doi:10.1146/annurev.es. 21.110190 .002231

Chapin, F. S. (1980). The Mineral Nutrition of Wild Plants. Annu. Rev. Ecol. Syst. 11 (1), 233-260. doi:10.1146/annurev.es.11.110180.001313

Charman, D. (2002). Peatlands and Environmental Change. New York: John Wiley \& Sons.

Cong, Y., Li, M.-H., Liu, K., Dang, Y.-C., Han, H.-D., and He, H. S. (2019). Decreased Temperature with Increasing Elevation Decreases the End-Season Leaf-To-Wood Reallocation of Resources in Deciduous Betula Ermanii Cham. Trees. Forests 10 (2), 166. doi:10.3390/f10020166

Cong, Y., Wang, A., He, H., Yu, F., Tognetti, R., Cherubini, P., et al. (2018). Evergreen Quercus Aquifolioides Remobilizes More Soluble Carbon Components but Less $\mathrm{N}$ and $\mathrm{P}$ from Leaves to Shoots Than Deciduous Betula Ermanii at the End-Season. iForest 11 (4), 517-525. doi:10.3832/ ifor2633-011

Dickson, R. E. (1989). Carbon and Nitrogen Allocation in Tree. Ann. des Sci. Forestières 46 (Suppl. ment), 347-350. doi:10.1051/forest:198905art0142

Dissanayaka, D. M. S. B., Maruyama, H., Nishida, S., Tawaraya, K., and Wasaki, J. (2017). Landrace of Japonica rice, Akamai Exhibits Enhanced Root Growth and Efficient Leaf Phosphorus Remobilization in Response to Limited Phosphorus Availability. Plant and Soil 414 (1/2), 327-338. doi:10.1007/s11104-016-3129-1

Dubois, M., Gilles, K. A., Hamilton, J. K., Rebers, P. A., and Smith, F. (1956). Colorimetric Method for Determination of Sugars and Related Substances. Anal. Chem. 28, 350-356. doi:10.1021/ac60111a017

\section{FUNDING}

$\mathrm{MJ}$ and $\mathrm{YuC}$ were supported by the National Natural Science Foundation of China (Grant No. U19A2042, 42001106). BL was funded by the Natural Science Foundation of Jilin Province, China (Grant No. 20200201195JC).

\section{ACKNOWLEDGMENTS}

We sincerely thank Xinhua Zhou and Haiyang Zhao for chemical analysis, and Huiyuan Sun for her assistance in the laboratory.

Eckstein, R. L., Karlsson, P. S., and Weih, M. (1998). The Significance of Resorption of Leaf Resources for Shoot Growth in Evergreen and Deciduous Woody Plants from a Subarctic Environment. Oikos 81 (3), 567-575. doi:10.2307/3546777

Epron, D., Bahn, M., Derrien, D., Lattanzi, F. A., Pumpanen, J., Gessler, A., et al. (2012). Pulse-labelling Trees to Study Carbon Allocation Dynamics: A Review of Methods, Current Knowledge and Future Prospects. Tree Physiol. 32, 776-798. doi:10.1093/treephys/tps057

Gessner, M. O. (2001). Mass Loss, Fungal Colonisation and Nutrient Dynamics of Phragmites Australis Leaves during Senescence and Early Aerial Decay. Aquat. Bot. 69 (2), 325-339. doi:10.1016/s0304-3770(01)00146-2

Granéli, W., Weisner, S. E. B., and Sytsma, M. D. (1992). Rhizome Dynamics and Resource Storage in Phragmites Australis. Wetlands Ecol. Manage. 1 (4), 239-247.

Jonasson, S., and Shaver, G. R. (1999). Within-stand Nutrient Cycling in Arctic and Boreal Wetlands. Ecology 80 (7), 2139-2150. doi:10.1890/0012-9658(1999)080 [2139:wsncia]2.0.co;2

Killingbeck, K. T. (1996). Nutrients in Senesced Leaves: Keys to the Search for Potential Resorption and Resorption Proficiency. Ecology 77 (6), 1716-1727. doi: $10.2307 / 2265777$

Li, M.-H., Jiang, Y., Wang, A., Li, X., Zhu, W., Yan, C.-F., et al. (2018). Active Summer Carbon Storage for winter Persistence in Trees at the Cold alpine Treeline. Tree Physiol. 38 (9), 1345-1355. doi:10.1093/treephys/tpy020

Li, M.-H., Xiao, W.-F., Shi, P., Wang, S.-G., Zhong, Y.-D., Liu, X.-L., et al. (2008). Nitrogen and Carbon Source-Sink Relationships in Trees at the Himalayan Treelines Compared with Lower Elevations. Plant Cel Environ. 31 (10), 1377-1387. doi:10.1111/j.1365-3040.2008.01848.x

Li, M., Hoch, G., and Körner, C. (2002). Source/sink Removal Affects mobile Carbohydrates in Pinus Cembra at the Swiss Treeline. Trees 16 (4-5), 331-337. doi:10.1007/s00468-002-0172-8

Li, M., Hoch, G., and Körner, C. (2001). Spatial Variability of mobile Carbohydrates within Pinus Cembra Trees at the alpine Treeline. PhytonAnnales Rei Botanicae 41, 203-213.

Li, T., Bu, Z., Liu, W., Zhang, M., Peng, C., Zhu, Q., et al. (2019). Weakening of the 'enzymatic Latch' Mechanism Following Long-Term Fertilization in a Minerotrophic Peatland. Soil Biol. Biochem. 136, 107528. doi:10.1016/j. soilbio.2019.107528

Maimer, N., Horton, D. G., and Vitt, D. H. (1992). Element Concentrations in Mosses and Surface Waters of Western Canadian Mires Relative to Precipitation Chemistry and Hydrology. Ecography 15 (1), 114-128. doi:10. 1111/j.1600-0587.1992.tb00015.x

Marchi, S., Guidotti, D., Sebastiani, L., and Tognetti, R. (2007). Changes in Assimilation Capacity during Leaf Development in Broad-Leaved Prunus Persica and Sclerophyllous Olea Europaea. J. Hortic. Sci. Biotechnol. 82 (1), 69-78. doi:10.1080/14620316.2007.11512201

Marchi, S., Sebastiani, L., Gucci, R., and Tognetti, R. (2005a). Changes in SinkSource Relationships during Shoot Development in Olive. jashs 130, 631-637. doi:10.21273/jashs.130.4.631

Marchi, S., Sebastiani, L., Gucci, R., and Tognetti, R. (2005b). Sink-source Transition in Peach Leaves during Shoot Development. jashs 130, 928-935. doi:10.21273/jashs.130.6.928 
Millard, P., and Grelet, G.-A. (2010). Nitrogen Storage and Remobilization by Trees: Ecophysiological Relevance in a Changing World. Tree Physiol. 30, 1083-1095. doi:10.1093/treephys/tpq042

Millard, P., Hester, A., Wendler, R., and Baillie, G. (2001). Interspecific Defoliation Responses of Trees Depend on Sites of winter Nitrogen Storage. Funct. Ecol. 15 (4), 535-543. doi:10.1046/j.0269-8463.2001.00541.x

Morin, X., Ameglio, T., Ahas, R., Kurz-Besson, C., Lanta, V., Lebourgeois, F., et al. (2007). Variation in Cold Hardiness and Carbohydrate Concentration from Dormancy Induction to Bud Burst Among Provenances of Three European Oak Species. Tree Physiol. 27, 817-825. doi:10.1093/treephys/27. 6.817

Murphy, J., and Riley, J. P. (1962). A Modified Single Solution Method for the Determination of Phosphate in Natural Waters. Analytica Chim. Acta 27, 31-36. doi:10.1016/s0003-2670(00)88444-5

Ohlson, M. (1995). Growth and Nutrient Characteristics in Bog and Fen Populations of Scots pine (Pinus Sylvestris). Plant Soil 172 (2), 235-245. doi:10.1007/bf00011326

Parkinson, J. A., and Allen, S. E. (1975). A Wet Oxidation Procedure Suitable for the Determination of Nitrogen and mineral Nutrients in Biological Material. Commun. Soil Sci. Plant Anal. 6 (1), 1-11. doi:10.1080/00103627509366539

Pensa, M., and Sellin, A. (2003). Soil Type Affects Nitrogen Conservation in Foliage of Small Pinus Sylvestris L. Trees. Plant and Soil 253 (2), 321-329. doi:10.1023/ a:1024884516655

Pugnaire, F. I., and Chapin, F. S., III (1993). Controls over Nutrient Resorption from Leaves of Evergreen Mediterranean Species. Ecology 74 (1), 124-129. doi: $10.2307 / 1939507$

Qiao, S. (1993). A Preliminary Study on Hani Peat Mire in the West Part of the Changbai Mountain. Scientia Geographica Sinica.

Rydin, H., Clymo, R. S., and Fogg, G. E. (1989). Transport of Carbon and Phosphorus Compounds about Sphagnum. Proc. R. Soc. Lond. B. Biol. Sci. 237 (1286), 63-84.

Sheen, J., Zhou, L., and Jang, J.-C. (1999). Sugars as Signaling Molecules. Curr. Opin. Plant Biol. 2 (5), 410-418. doi:10.1016/s1369-5266(99)00014-x

Tixier, A., Guzmán-Delgado, P., Sperling, O., Amico Roxas, A., Laca, E., and Zwieniecki, M. A. (2020). Comparison of Phenological Traits, Growth Patterns, and Seasonal Dynamics of Non-structural Carbohydrate in Mediterranean Tree Crop Species. Sci. Rep. 10 (1), 347. doi:10.1038/s41598-019-57016-3

Turetsky, M. R., Bond-Lamberty, B., Euskirchen, E., Talbot, J., Frolking, S., McGuire, A. D., et al. (2012). The Resilience and Functional Role of moss in Boreal and Arctic Ecosystems. New Phytol. 196 (1), 49-67. doi:10.1111/j. 1469-8137.2012.04254.x

Vergutz, L., Manzoni, S., Porporato, A., Novais, R. F., and Jackson, R. B. (2012). Global Resorption Efficiencies and Concentrations of Carbon and Nutrients in Leaves of Terrestrial Plants. Ecol. Monogr. 82 (2), 205-220. doi:10.1890/110416.1

Wang, A., Wang, X., Tognetti, R., Lei, J.-P., Pan, H.-L., Liu, X.-L., et al. (2018). Elevation Alters Carbon and Nutrient Concentrations and Stoichiometry in
Quercus Aquifolioides in Southwestern China. Sci. Total Environ. 622-623, 1463-1475. doi:10.1016/j.scitotenv.2017.12.070

Wang, M., Murphy, M. T., and Moore, T. R. (2014). Nutrient Resorption of Two evergreen Shrubs in Response to Long-Term Fertilization in a Bog. Oecologia 174 (2), 365-377. doi:10.1007/s00442-013-2784-7

Waughman, G. J. (1980). Chemical Aspects of the Ecology of Some South German Peatlands. J. Ecol. 68 (3), 1025-1046. doi:10.2307/2259473

Wyka, T. P., Karolewski, P., Żytkowiak, R., Chmielarz, P., and Oleksyn, J. (2016). Whole-plant Allocation to Storage and Defense in Juveniles of Related evergreen and Deciduous Shrub Species. Tree Physiol. 36 (5), 536-547. doi:10.1093/treephys/tpv108

Yan, C. F., Gessler, A., Rigling, A., Dobbertin, M., Han, X. G., and Li, M. H. (2016). Effects of Mistletoe Removal on Growth, $\mathrm{N}$ and $\mathrm{C}$ Reserves, and Carbon and Oxygen Isotope Composition in Scots pine Hosts. Tree Physiol. 36, 562-575. doi:10.1093/treephys/tpw024

Yuan, Z.-Y., Li, L.-H., Han, X.-G., Huang, J.-H., Jiang, G.-M., Wan, S.-Q., et al. (2005). Nitrogen Resorption from Senescing Leaves in 28 Plant Species in a Semi-arid Region of Northern China. J. Arid Environments 63 (1), 191-202. doi:10.1016/j.jaridenv.2005.01.023

Yuan, Z. Y., and Chen, H. Y. H. (2009). Global-scale Patterns of Nutrient Resorption Associated with Latitude, Temperature and Precipitation. Glob. Ecol. Biogeogr. 18 (1), 11-18. doi:10.1111/j.1466-8238.2008.00425.x

Zhu, W.-Z., Cao, M., Wang, S.-G., Xiao, W.-F., and Li, M.-H. (2012). Seasonal Dynamics of Mobile Carbon Supply in Quercus Aquifolioides at the Upper Elevational Limit. PloS one 7, e34213. doi:10.1371/journal.pone. 0034213

Ziegler, H. (1964). "Storage, Mobilization and Distribution of Reserve Material in Trees," in Formation of Wood in Forest Trees. Editor M. Zimmermann (New York: Academic Press), 303-320. doi:10.1016/b978-1-4832-2931-7.50022-7

Conflict of Interest: The authors declare that the research was conducted in the absence of any commercial or financial relationships that could be construed as a potential conflict of interest.

Publisher's Note: All claims expressed in this article are solely those of the authors and do not necessarily represent those of their affiliated organizations, or those of the publisher, the editors, and the reviewers. Any product that may be evaluated in this article, or claim that may be made by its manufacturer, is not guaranteed or endorsed by the publisher.

Copyright (c) 2022 Cong, Zhang, Liu, Chen, Li, Jiang and Li. This is an open-access article distributed under the terms of the Creative Commons Attribution License (CC $B Y)$. The use, distribution or reproduction in other forums is permitted, provided the original author(s) and the copyright owner(s) are credited and that the original publication in this journal is cited, in accordance with accepted academic practice. No use, distribution or reproduction is permitted which does not comply with these terms. 